\title{
Nuclear changes in Bacillus anthracis and their Relation to Variants
}

\author{
BY T. H. FLEWETT \\ The Institute of Pathology, Queen's University, Belfast
}

SUMMARY: The nuclear changes leading to spore formation in Bacillus anthracis were investigated in 35 strains. Fusion of four chromatinic bodies into one mass and its subsequent break up into four bodies was observed. One of these became incorporated in the spore; the other three disintegrated. Some cells showed no fusion before spore formation; in these one chromatinic body was incorporated in the spore and the other three disintegrated. The percentage of cells in which fusion occurred varied with the strain. Rough colony strains showing a high incidence of fusion tended readily to throw smooth colony variants. Strains showing a low incidence of fusion were stable in this respect. The incidence of variants of other types bore no relation to the incidence of nuclear fusion in the strain.

Nuclear structures in the spore-forming aerobic bacilli were described by Nakanishi'(1901), Badian (1933), Stille (1937), Piekarski (1938), and in greater detail by Robinow (1942), who studied them particularly in spore germination and in the early logarithmic phase of growth. Badian described the fusion of the nuclear elements into one mass and its subsequent breaking up into four parts before spore formation; he recognized that one body entered the spore while the remaining three disintegrated. Klieneberger-Nobel (1945) observed fusion of chromatinic structures both in aerobic and anaerobic spore-forming organisms, and also in a non-spore-forming organism, Sphaerotilus natans. In later papers $(1947 a, b)$ she described the changes occurring in myxobacteria and actinomyces, and showed that fusion of chromatinic structures occurred also among them. It was suggested both by Badian and Klieneberger-Nobel that this fusion might represent an autogamic mechanism.

\section{MATERIALS AND METHODS}

The following 35 strains of Bacillus anthracis were examined.

A. National Collection of Type Cultures: nos. 109 (Paddington VI); 1328; 1712 (Pasteur's Second Vaccine); 1607; 2620 (Hankow Hide); 4991, 5130, $5249,7200$.

B. Strains isolated from a recent shipment of sheep hides, many of which were contaminated, causing a human infection: strains $\mathrm{A}, \mathrm{Cl}, \mathrm{CC2}, \mathrm{H2}, \mathrm{H3}$, H5, H7, H8, F1, H3 F2, mouse F, mouse 5.

C. Strains isolated from the lesions of human and bovine infections: Hillsborough, Newtownards, Carrickfergus, R.V.H., Tinsdale, McLean 1 A, McLean 2, Lindsay, Davis.

D. Strains maintained in this laboratory: A/stock, S/stock, Dean, 2160, 2161.

The media used were Lemco broth, pH 7·6, and Lemco agar (2\% agar), pH 7·6. 
The staining methods described by Robinow (1944) were used to demonstrate the nuclear structures. For the study of 'spore germination and of young cultures up to $4 \mathrm{hr}$. old, the agar was cut into strips and mounted on coverslips, with the organisms outwards, and fixed in the vapour of $2 \%$ osmic tetroxide for 3-5 min. A second cover-slip was then placed on the agar surface, and the two cover-slips with the agar between them immersed in $30 \%$ ethanol for 2-3 hr. The second cover-slip, bearing most of the organisms upon it was then removed and placed for a few minutes in Schaudinn's fixative, then in $\mathrm{N}-\mathrm{HCl}$ at $56^{\circ}$ for $7 \mathrm{~min}$., washed, and stained with Giemsa's stain (0.15-2 ml. phosphate buffer, $\mathrm{pH} \mathrm{6.2)} \mathrm{for} \mathrm{10-15} \mathrm{min.} \mathrm{For} \mathrm{the} \mathrm{details} \mathrm{of} \mathrm{this} \mathrm{technique,}$ I am indebted to Dr C. F. Robinow (personal communication).

For older cultures, a portion of growth was emulsified in a small drop of water, allowed to dry, and immediately fixed in osmic tetroxide vapour, hydrolyzed and stained as above. All preparations were made on cover-slips. It was found that a more transparent stain was produced by diluting the Giemsa stain with a mixture of 2 vol. horse serum and 1 vol. $\mathrm{M} / 200$ phosphate buffer, pH 6.2.

Fat inclusions were stained by the method of Burdon, Stokes \& Kimbrough (1942).

All preparations were examined and photographed mounted in water or in the staining solution.

Optical equipment. The optical equipment consisted of a $2 \mathrm{~mm}$. Leitz apochromatic objective, N.A. 1.32, with compensating eyepieces $\times 12$ for photography and $\times \mathbf{2 0}$ for visual work, and a Watson 'Holoscopic' oil immersion condenser, N.A. 1-3. Critical illumination was used throughout. A green filter was used both for photography and for visual work. It was impossible to resolve some of the structures without oil immersion of the condenser.

\section{RESULTS}

The changes found in spore germination confirm the results of Robinow (1942). The spores of $B$. anthracis, however, take 60-75 min. to germinate, a much longer time than that taken by the spores of his strain of B. mycoides.

In the earlier stage of logarithmic growth the rods contain dumb-bell-shaped bodies which divide at right angles to the long axis of the cell (P1. 1, figs. 1, 2; Fig. 1A). When they separate they leave between them a single thread of chromatin which later ruptures. In the rough colony variants the chromatinic bodies are widely separated. In the smooth colony variants they are closer together, and the intercellular septa occur at an earlier stage than in the rough phase.

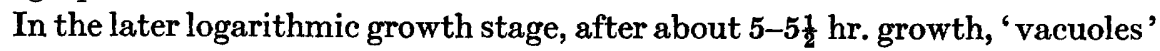
appear in between the dividing chromatinic bodies; and now, instead of a single chromatin thread joining the separating bodies, two threads can be seen (Pl. 1, fig. 3; Fig. 1B), which are separated by the 'vacuole'. The nature of this 'vacuole' is not certain. Vacuoles may often be seen by dark:ground illumination after about $5 \mathrm{hr}$. growth in a position corresponding to that of the 
spaces seen in the Giemsa-stained preparation. They often contain a small granule in violent Brownian movement, showing that the contents are fluid. In many strains fat globules can be stained by Sudan Black in $5 \mathrm{hr}$. cultures corresponding in position to the vacuoles seen in dark ground and in the Giemsa-stained preparations.

From $5 \frac{1}{2}$ to $10 \mathrm{hr}$. of growth (the time varying from one strain to another, but fairly constant for the same strain on the same medium) four (occasionally eight) chromatinic bodies become joined end to end and then fuse into a single chromatin rod in the long axis of the cell. At this stage the vacuoles disappear (Pl. 1, fig. 4; Fig. 1C-E). Fusion occurs only in a certain percentage of the cells; with some strains, in less than $1 \%$, with others, in over $95 \%$. Just before this stage, each cell contains four chromatinic bodies, surrounded by a cell membrane; a few cells contain eight. The cells which do not show this change remain as before, with their chromatin structures in pairs separated by vacuoles. As a rule, the axial chromatin rods remain unchanged for at least 45 min. : in one strain (N.C.T.C. 1328) they persisted for nearly $8 \mathrm{hr}$. Vacuoles then appear in the rods ( $\mathrm{Pl}$. 1, figs. 5-7; Fig. 1F, G) which break up to form four chromatinic bodies in two pairs, the members of each pair separated by a vacuole. Around any one of the four chromatinic bodies an eosinophil substance is laid down, usually around the terminal body (Pl. 2, fig. 8; Fig. 1G; cf. the diagrams of Badian and Klieneberger-Nobel). A limiting membrane around this eosinophilic area could not be seen. This eosinophil substance increases in size and becomes the spore body. Inside it the chromatinic body becomes orientated into the long axis of the cell, and then becomes spherical in shape. It increases in size, until the whole spore body becomes so densely basophilic that no internal structure can be distinguished (Pl. 2, figs. 9-13; Fig. 1H-J). The appearance is similar to that seen in one stage of the germinating spore. The basophilic material then clears and the chromatinic body appears lying on the surface of the spore body. Meanwhile, the three remaining chromatinic bodies disintegrate, and eventually the rest of the cell disappears leaving the free spore (Pl. 2, fig. 14; Fig. 1K, L). The cells in which fusion of nuclear substance does not take place go on to spore formation in the same way.

Attempts were made to induce fusion of nuclei in strains in which this rarely happened. Following a suggestion of Dr Klieneberger-Nobel, cultures at various stages of growth of the strain 'Carrickfergus' were examined after $3 \mathrm{hr}$. at $0^{\circ}$. Clumping of the chromatinic bodies occurred in the early stage of logarithmic growth (Pl. 2, fig. 15; Fig. 1M), but at the stage immediately before spore formation, when fusion might have been expected, no fusion occurred, possibly because of the vacuoles between them.

When this strain was grown on Lemco agar containing $1 / 2000(\mathrm{w} / \mathrm{v}) \mathrm{CaCl}_{2}$, as recommended by Bordet \& Renaux (1930) for production of asporogenous variants, about $15 \%$ of fusion cells occurred, instead of the usual $1 \%$. Similarly, the strain Hankow Hide, normally producing about $40 \%$ fusion cells, produced over $90 \%$ when grown on this medium.

For the estimation of the percentage of cells in which nuclear fusion took 
place, the Lemco agar plate was heavily and evenly inoculated over an area of at least 2 sq.in., so that the cells in preparations made from the centre of this area were as nearly as possible at the same stage of development. In strains showing almost $100 \%$ nuclear fusion, few preparations were necessary; in strains whose cells showed little fusion, very many preparations were made

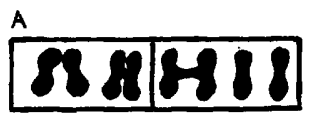

Smooth form

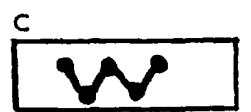

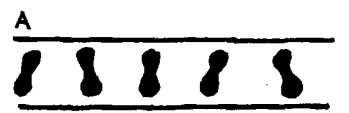

Rough form

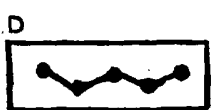

B

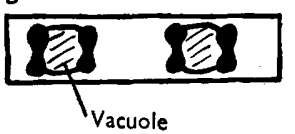

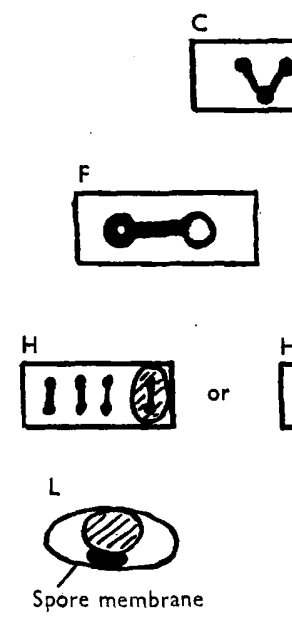
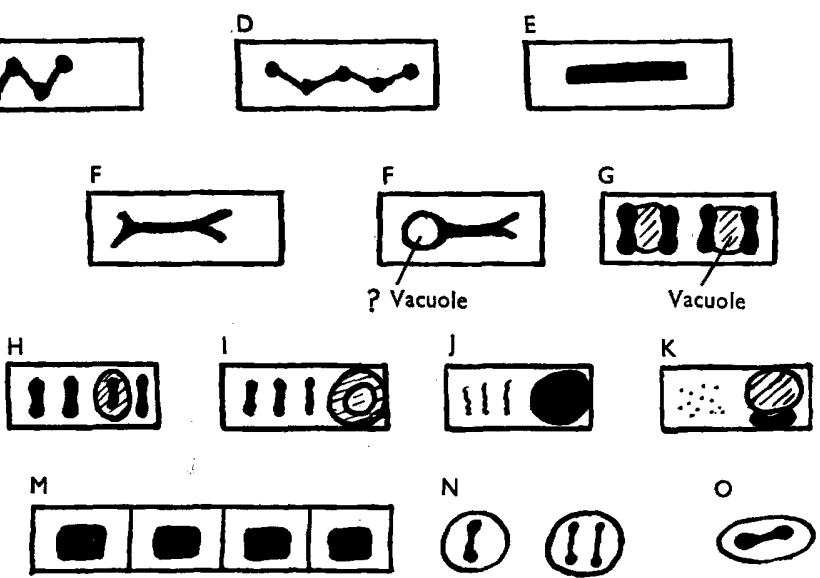

0

Fig. 1.

to ensure that fusion was not taking place. The figures in Table 1 are those of the preparations showing the highest incidence of fusion cells found in the strain in question.

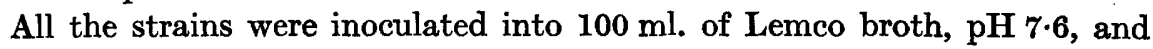
incubated at $37^{\circ}$. The cultures were thoroughly shaken after 10 and 17 days' growth and plated out to give single colonies. Between 50 and 100 colonies of each strain were examined. The 17-day period was chosen because variation takes place in most strains of $\boldsymbol{B}$. anthracis by this time; and if cultures in a large volume of broth are incubated longer, motile variants sometimes appear. When this happens all or nearly all of the colonies found on plating are smooth colony motile variants; the other forms are overgrown in the flasks. In estimating the incidence of cells showing fusion the difficulty was greatest in strains showing an incidence between 10 and $90 \%$; some cells are seen in which it is hard to decide whether or not an early or late stage of fusion is taking place. Over this range the percentage error is probably at least $\pm 10 \%$. In the table the letter ' $R$ ' indicates the rough medusa-head colony variant and ' $S$ ' the smooth, usually avirulent, colony variant. ' $R S$ ' indicates the intermediate form.

Bacteriophage was present in the strains $\mathrm{C1}, \mathrm{H} 2$, and F1. The strain C1, 
Table 1. The incidence of nuclear fusion in variants of Bacillus anthracis

\begin{tabular}{|c|c|c|c|}
\hline Strain & $\begin{array}{l}\text { Incidence } \\
\text { of fusion } \\
(\%)\end{array}$ & $\begin{array}{l}\text { Type of colonies after } \\
10 \text { days' incubation }\end{array}$ & $\begin{array}{l}\text { Type of colonies after } \\
17 \text { days' incubation }\end{array}$ \\
\hline N.C.T.C. 109 & 70 & All $\mathbf{R}$ & $\begin{array}{l}\text { RS } 20 \% \\
\text { R } 80 \%\end{array}$ \\
\hline N.C.T.C. 1328 & 30 & All $\mathbf{R}$ & All $\mathbf{R}$ \\
\hline N.C.T.C. 1607 & 4 & All $\mathbf{R}$ & All $\mathbf{R}$ \\
\hline N.C.T.C. 1712 & 95 & All $\mathbf{R}$ & $\begin{array}{l}\text { S } 52 \% \\
\text { R } 48 \%\end{array}$ \\
\hline N.C.T.C. 2620 & 40 & All $\mathbf{R}$ & $\begin{array}{l}\text { A few coccal variants } \\
\text { Remainder } \mathbf{R}\end{array}$ \\
\hline N.C.T.C. 4991 & 90 & All $\mathbf{R}$ & $\begin{array}{l}\text { S } 12 \% \\
\text { RS } 67 \% \\
\text { R } 15 \%\end{array}$ \\
\hline N.C.T.C. 5130 & $\mathbf{1}$ & All $\mathbf{R}$ & $\begin{array}{l}\text { S } 1 \% \\
\text { RS } 1 \% \\
\text { Remainder R }\end{array}$ \\
\hline N.C.T.C. 5249 & 95 & All $\mathbf{R}$ & $\begin{array}{l}\text { S } 40 \% \\
\text { RS } 33 \% \\
\text { R } 27 \%\end{array}$ \\
\hline N.C.T.C. 7200 & 20 & All $\mathbf{R}$ & All $\mathbf{R}$ \\
\hline & $\mathbf{1}$ & All $\mathbf{R}$ & All R \\
\hline $\mathrm{CC} 2$ & 10 & $\begin{array}{l}\text { RS 1 } \% \\
\text { R 99\% }\end{array}$ & $\begin{array}{l}\text { RS 5\% } \\
\text { R 95\% }\end{array}$ \\
\hline H3 & 50 & $\begin{array}{l}\text { S } 50 \% \\
\text { R } 50 \%\end{array}$ & $\begin{array}{l}\text { RS } 60 \% \\
\text { R } 40 \%\end{array}$ \\
\hline H5 & 95 & $\begin{array}{l}\text { RS } 10 \% \\
\text { R } 90 \%\end{array}$ & $\begin{array}{l}\text { S 30\% } \\
\text { R 70\% }\end{array}$ \\
\hline $\mathrm{Hr}$ & 80 & All $\mathrm{R}$ & $\begin{array}{l}\text { S } 20 \% \\
\text { RS 35\% } \\
\text { R 45\% }\end{array}$ \\
\hline H3 F3 & 60 & $\begin{array}{l}\text { S } 30 \% \\
\text { R } 70 \%\end{array}$ & $\begin{array}{l}\text { S 30\% } \\
\text { R 30\% }\end{array}$ \\
\hline Mouse $\mathrm{F}$ & 95 & $\begin{array}{l}\text { RS } 1 \% \\
\text { R } 99 \%\end{array}$ & $\begin{array}{l}\text { RS } 30 \% \\
\text { R 70\% }\end{array}$ \\
\hline Mouse 5 & 5 & All $\mathbf{R}$ & All $\mathbf{R}$ \\
\hline Hillsborough & 1 & All $\mathbf{R}$ & All $\mathbf{R}$ \\
\hline Newtownards & 10 & $\begin{array}{l}\text { Ghost colonies (R) } \mathbf{5 0} \% \\
\text { R } \mathbf{5 0} \%\end{array}$ & $\begin{array}{l}\text { Ghost colonies } 70 \% \\
\text { R 70\% }\end{array}$ \\
\hline Carrickfergus & 2 & All $\mathbf{R}$ & All $\mathbf{R}$ \\
\hline R.V.H. & 20 & All $\mathbf{R}$ & $\begin{array}{l}\text { Coccal variants } 75 \% \\
\text { R } 25 \%\end{array}$ \\
\hline Tinsdale & 5 & All $\mathbf{R}$ & All $\mathbf{R}$ \\
\hline McClean IA & 10 & $\begin{array}{l}\text { Small smooth } 1 \% \\
\text { R 99\% }\end{array}$ & $\begin{array}{l}1 \text { coccal variant } \\
\text { Remainder } \mathbf{R}\end{array}$ \\
\hline McClean II & 40 & All $\mathbf{R}$ & $\begin{array}{l}\text { S } 65 \% \\
\text { R 35\% }\end{array}$ \\
\hline A/stock & 50 & All $\mathbf{R}$ & Coccal variants only \\
\hline S/stock & 25 & All $\mathbf{R}$ & All $\mathbf{R}$ \\
\hline Lindsay & 75 & $\begin{array}{l}\text { Coccal variants } 65 \% \\
\text { R 35\% }\end{array}$ & $\begin{array}{l}\text { S } 15 \% \\
\text { R } 85 \%\end{array}$ \\
\hline Dean & 70 & All RS as original & All S \\
\hline 2160 & 25 & All $\mathbf{R}$ & $\begin{array}{l}\text { S } 10 \% \\
\text { R 90\% }\end{array}$ \\
\hline 2161 & 60 & $\begin{array}{l}1 \text { smooth colony } \\
\text { Remainder } R\end{array}$ & $\begin{array}{l}\text { S } 4 \% \\
\text { R } 96 \%\end{array}$ \\
\hline Davis & 95 & $\begin{array}{l}\text { RS 5 \% } \\
\text { R 95\% }\end{array}$ & All $\mathbf{R}$ \\
\hline
\end{tabular}


with an incidence of fusion of $\mathbf{9 5} \%$ regularly produced about $50 \%$ of smooth colony variants after $24 \mathrm{hr}$. incubation. The strains $\mathrm{H} 2$ (fusion incidence $1 \%$ ) and $\mathrm{F} 1$ (fusion incidence $5 \%$ ) did not throw any smooth colony variants from broth cultures. (Smooth colony variants were obtained on plate culture from the strain F1 in the presence of bacteriophage of high titre which was specific for the rough colonies (N. C. Graham, personal communication).)

These results show that the occurrence of smooth colony variants in rough colony cultures is associated with a high incidence of cells showing fusion of the chromatinic bodies and that stability is associated with a low incidence. The only exceptions were the N.C.T.C. strain 5130, where one smooth and one RS colony were produced, and the strain 'Davis', where hardly any variation occurred. The occurrence of coccal and ghost-medusa colonies is not related to the incidence of nuclear fusion.

\section{DISCUSSION}

There can now be little doubt that the structures seen in bacteria stained by the osmic acid $\mathrm{HCl}$-Giemsa method represent the nuclear apparatus. They are present in all organisms examined which are large enough to show internal structure under the light microscope (Robinow, 1942, 1944; 1945 and Klieneberger-Nobel, 1945, 1947 $a, b)$. The distribution and appearance of these structures is similar by different staining methods: Nakanishi (1901), using a 'vital' method with methylene-blue; Dobell (1911) and Badian (1983), fixing with osmic acid or formalin, staining with Giemsa, and differentiating with $1 \%$ eosin solution; Stille (1937), Piekarski (1940), and Neumann (1941) using the Feulgen technique; Robinow and Klieneberger-Nobel using the osmic acid HCl-Giemsa method; all saw essentially the same structures.

The Feulgen stain in all other plant and animal tissues is specific for the desoxyribonucleic acid which is found only in nuclei and which is associated with the presence of genes. Vendrely \& Lehoult (1946) have estimated the dryweight percentage of ribonucleic and desoxyribonucleic acids and protein in staphylococci, B. anthracis and Escherichia coli. They found that the amount of desoxyribonucleic acid is in accord with the size of the nuclei described by Robinow, but that the nuclei of Stille and of Piekarski appear too small in their photographs. This may be due to the use of dehydrated and cleared prepárations by Stille and Piekarski, whereas Robinow's preparations were photographed mounted in water.

The spore contains one chromatinic body; the coccal variant of $B$. anthracis contains a single nuclear body (Pl. 2, fig. 16; Fig. $1 \mathrm{~N}$ ) and in the phase of growth of Proteus vulgaris just before swarming occurs, forms containing one chromatinic body occur (Klieneberger-Nobel, personal communication). The cells of Esch. coli and Proteus vulgaris (Robinow, 1944) and the cells of Corynebacterium diphtheriae in old cultures contain only one nuclear body ( $\mathrm{Pl} .2$, fig. 17; Fig. 10). It seems, therefore, that the bacterial individual must be considered as having a single nuclear body which may reasonably be considered as a chromosome; and that the rod form of young cultures of species like $E$ sch. 
coli and $B$. anthracis consists of several individuals still sharing a common cytoplasm and cell membrane. So the fusion cell of $B$. anthracis represents the fusion of four individual organisms which have arisen by two divisions from the same ancestral individual.

Appearances suggesting nuclear fusion are seen in the illustrations of Nakanishi (1901) and Dobell (1911), in the aerobic and anaerobic spore-formers. They have been more fully described by Badian (1933) and Klieneberger-Nobel $(1945,1947 a, b)$ in aerobic and anaerobic spore-forming organisms, myxococci and the aerobic actinomycetes. In a motile Gram-negative non-sporing bacillus Rosca (1937) described cells with $X$ and $Y$ chromosomes or nuclei which underwent fusion to form a diploid cell. His evidence is not convincing. Stapp (1942) described in Pseudomonas tumefaciens the formation of aggregates of rod forms like the spokes of a wheel with fusion of cytoplasm and chromatin in the centre, and their subsequent separation. His photographs are quite convincing. Zygospore formation has been described by Mellon (1925) in a rough strain of Esch. coli, but he did not demonstrate fusion of chromatin. The work of Lederberg \& Tatum (1946) and of Tatum \& Lederberg (1947) suggests that fusion of cells of one strain of Esch. coli may occur with those of another. They think that this does not necessarily occur in all strains, and that it may occur only rarely. It seems, therefore, that some form of fusion mechanism occurs widely among bacteria.

Lindegren (1935) postulated on theoretical grounds that a bacterial cell, having life, must possess genes arranged in a string that splits longitudinally in cell division. This linear arrangement of genes is probably represented by the dumb-bell-shaped chromosome. When the four chromosomes fuse, there may be an opportunity for interchange of position of genes on the chromosome. Change in the relative position of genes on the chromosome has been suggested by Darlington (1987) as a mechanism of variation in Drosophila, Chorthippus and Tulipa. There can, of course, be no doubt that change in the gene substance itself is also a mechanism for production of mutants.

The appearance when the fusion cylinder breaks up (PI. 1, figs. 5-7) is reminiscent of the appearance of the chiasmata in the diakinesis stage in meiosis of higher plants and animals; but it is possible that this appearance is due to the presence of the developing vacuole, and that it has no other significance.

The results suggest the importance of nuclear fusion as an autogamic process for the production of rough colony $\rightarrow$ smooth colony $\rightarrow$ motile variants. It is possible that the other variant colony types (coccal, ghost medusa, dwarf medusa, extreme rough) arise by means of gene mutation only; but this has yet to be proven.

I am greatly indebted to Dr C. F. Robinow, Dr N. C. Graham, and Dr E. O. Bartley for their interest, help, and criticism in this investigation, and to Dr Robinow also for details of technique and photography. 


\section{REFERENCES}

Badian, J. (1933). Eine zytologische Untersuchung über das Chromatin und den Entwicklungszyklus der Bacterien. Arch. Mikrobiol. 4, 409.

Bartley, E. O. (1930). The dissociation of Bacillus anthracis. M.D. Thesis, Belfast.

Bordet, J. \& Renaux, E. (1930). L'influence du calcium sur l'évolution des cultures de charbon. Ann. Inst. Pasteur, 45, 1.

Burdon, K. L., Stokes, J. C. \& Kimbrough, C. E. (1942). Studies of the common aerobic spore-forming bacilli. Staining for fat with Sudan Black B-Safranin. J. Bact. 43, 717.

Darlington, C. D. (1937). Recent Advances in Cytology, 2nd ed. London: J. and A. Churchill.

Dobeld, C. C. (1911). Contributions to the cytology of the bacteria. Quart. J. micr. Sci. 56, 395.

KLIENEBerger-Nobel, E. (1945). Changes in the nuclear structure of bacteria, particularly during spore formation. J. Hyg., Camb., 44, 99.

KutENEBERger-Nobex, E. $(1947 a)$. The life cycle of sporing Actinomyces as revealed by a study of their structure and septation. J. gen. Microbiol. 1, 22.

KuIENEBerger-Nobel, E. (1947 $b$ ). A cytological study of myxococci. J. gen. Microbiol. 1, 33.

Lederberg, J. \& TAtum, E. L. (1946). Gene recombination in Escherichia coli. Nature, Lond., 156, 558.

Lindegren, C. C. (1935). Genetical studies of bacteria. 1. The problem of the bacterial nucleus. Zbl. Bakt. (2. Abt.), 92, 40.

Mellon, R. R. (1925). Studies in microbic heredity. 1. Observations on a primitive form of sexuality (zygospore formation) in the colon-typhoid group. J. Bact. 10,481 .

Neumann, F. (1941). Untersuchungen zur Erforschung der Kernverhältnisse bei den Bakterien. Z Zbl. Bakt. (2. Abt.), 103, 385.

Nakanishi, K. (1901). Ueber den Bau der Bacterien. Zbl. Bakt. (l. Abt.), 30, 97.

Piekarski, G. (1940). Ueber kernähnliche Strukturen bei Bacillus mycoides Fluegge. Arch. Mikrobiol. 11, 406.

Robinow, C. F. (1942). A study of the nuclear apparatus of bacteria. Proc. Roy. Soc. B, 130, 299.

RoBinow, C. F. (1944). Cytological observations on Bact. coli, Proteus vulgaris, and various aerobic spore-forming bacteria, with special reference to the nuclear structures. J. Hyg., Camb., 43, 413.

Rosinow, C. F. (1945). Nuclear apparatus and cell structure of rod-shaped bacteria. Addendum in R. J. Dubos, The Bacterial Cell, in its Relation to Problems of Virulence, Immunity, and Chemotherapy. Cambridge, Mass., U.S.A.: Havard University Press.

RoscA, V. (1937). Contributions à l'étude de la structure cytologique des bactéries (2me. memoire). Arch. roum. Path. exp. Microbiol. 10, 267.

Stapp, C. (1942). Der Pflanzenkrebs und sein Erreger Pseudomonas tumefaciens. XI. Mitteilung. Zytologische Untersuchungen des bakteriellen Erregers. $\mathbf{Z} b l$. Bakt. (2. Abt.), 105, 1.

Stille, B. (1937). Zytologische Untersuchungen an Bacterien mit Hilfe der Feulgenschen Nuklealreaktion. Arch. Mikrobiol. 8, 125.

Tatum, E. L. \& Lederberg, J. (1947). Gene recombination in the bacterium Escherichia coli. J. Bact. 53, 673.

Vendrely, V. R. \& Lehoult, Y. (1946). Les acides ribo- et desoxyribonucléiques de la cellule bactérienne et leur signification. C.R. Acad. Sci., Paris, 222, 1357. 
Journal of General Microbiology, Vol. 2, No. 3

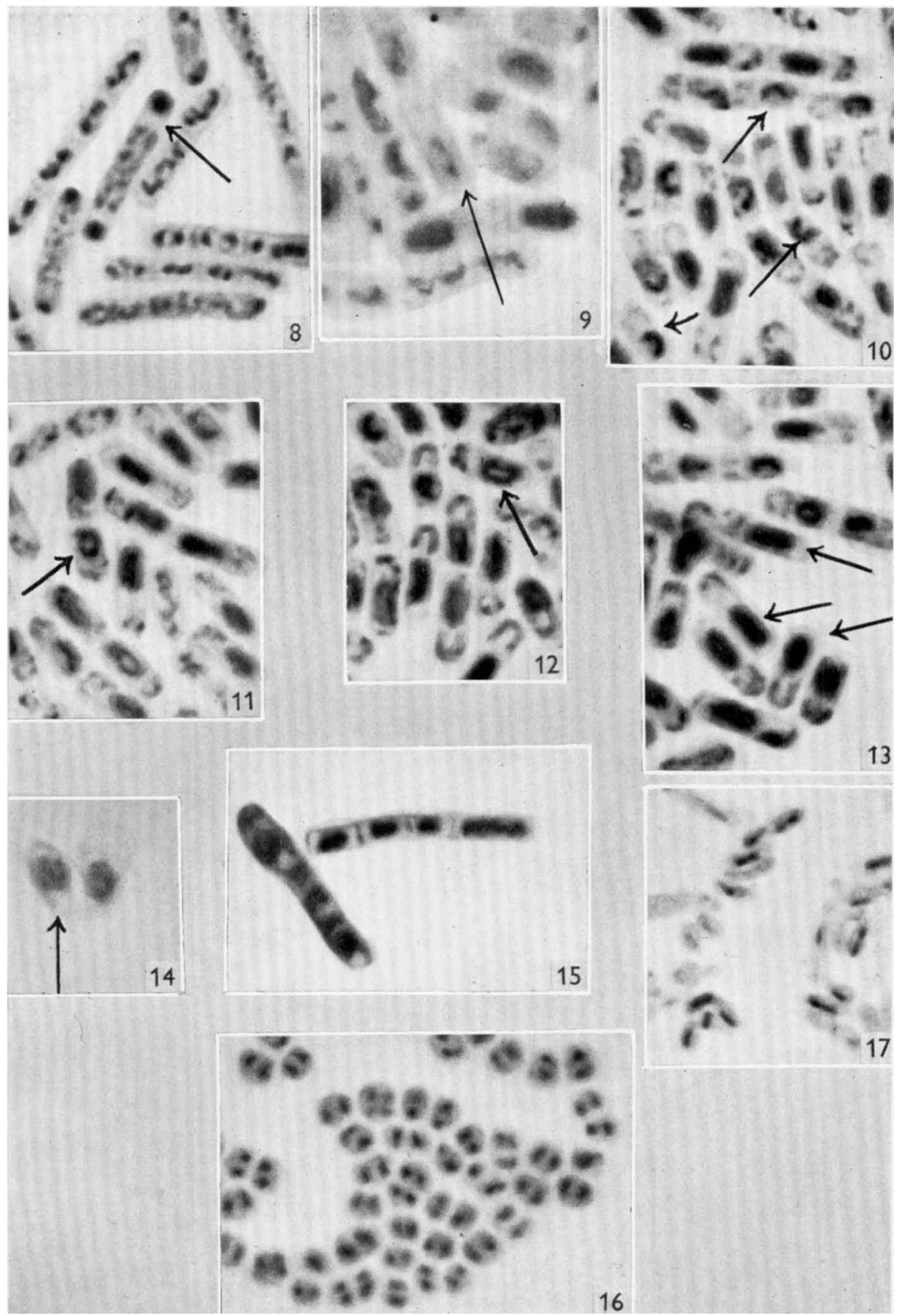

Figs. 8-17

T. H. Flewett- Necliak changes in Bachlles anthracis and their relation to variants. Plate 2 
Journal of General Microbiology, Vol. 2, No. 3

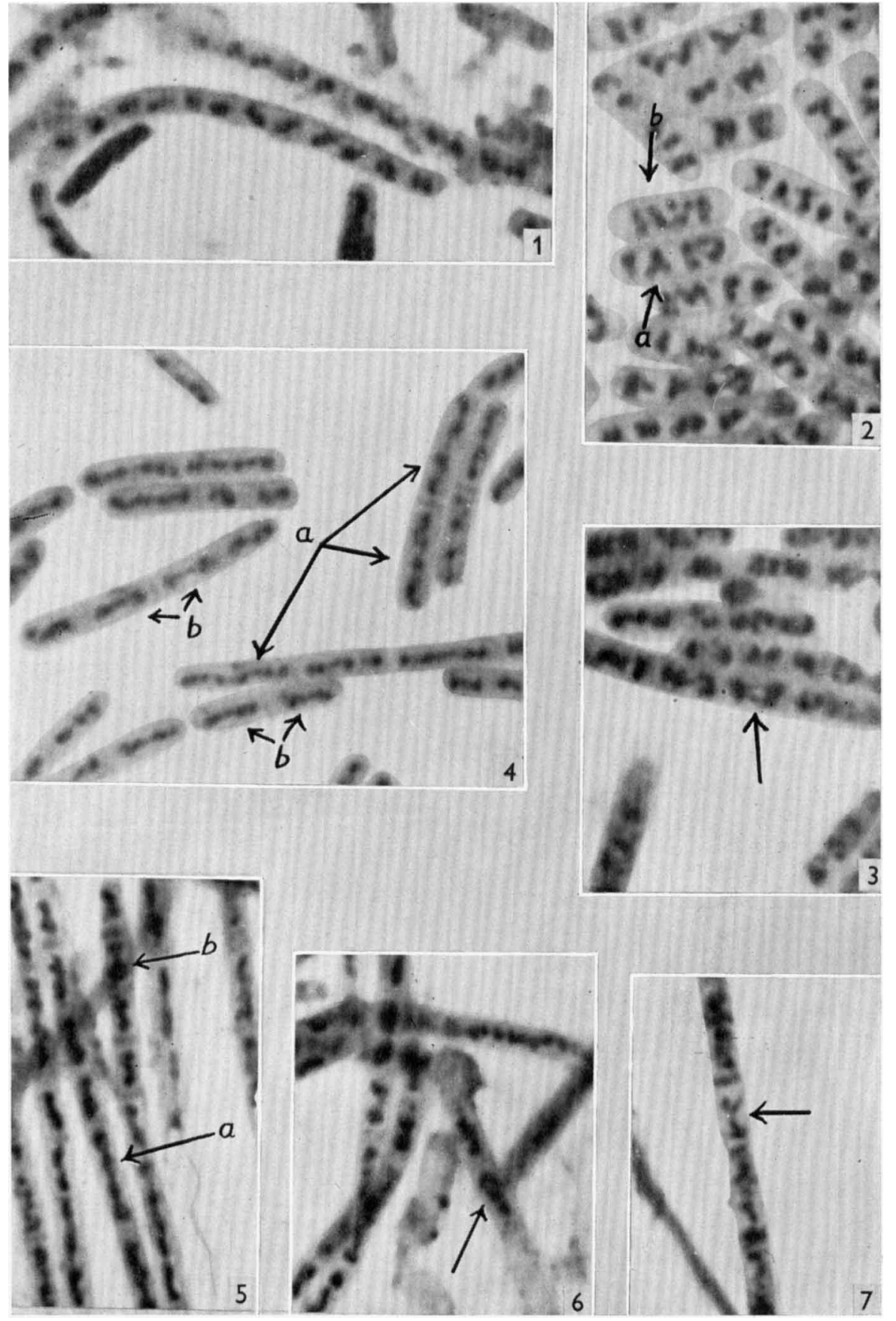

Figs. 1-7

T. H. Flewet'-Nuclear changes in Bacillus anthracis and their relation to varian'ts. Plate 1 


\section{Nuclear cycle and variation in Bacillus anthracis}

\section{EXPLANATION OF PLATES}

\section{Plate 1}

All photographs were of cover-slip preparations mounted in water. Magnification $\times 4000$.

Fig. 1. Strain Hankow Hide, rough colony type, after $3 \frac{1}{2} \mathrm{hr}$. incubation, showing widely spaced chromosomes.

Fig. 2. Strain $\mathrm{C1}$, smooth colony type, after $3 \frac{1}{2} \mathrm{hr}$. incubation, showing $(a)$ incomplete division of chromosomes, and $(b)$ divided chromosomes lying close together. The chromosomes are more closely spaced than in Fig. 1. Photograph by Dr C. F. Robinow.

Fig. 3. Strain Carrickfergus, after $4 \frac{1}{2} \mathrm{hr}$. incubation, showing separating chromosomes connected by two threads of chromatin enclosing a vacuole.

Fig. 4. Strain Hankow Hide, after $7 \mathrm{hr}$. incubation on agar containing $\mathrm{CaCl}_{\mathbf{2}} 1: 2000$ (w/v), showing (a) chromosomes joined end to end, and $(b)$ complete fusion.

Fig. 5. Strain and medium as in Fig. $4 ; 7 \frac{1}{2} \mathrm{hr}$. incubation. Stages in the breaking up of the fusion cylinders: $(a)$ a long form, probably derived from eight chromosomes, and (b) a short form derived from four chromosomes.

Figs. 6 and 7. Strain and medium as in Fig. 4, showing appearances suggestive of chiasma formation.

\section{Plate 2}

Fig. 8. Strain Carrickfergus, $8 \mathrm{hr}$. incubation on ordinary agar, showing an early stage of the spore; the remaining chromatin material is indistinct.

Fig. 9. Strain C1. A later stage than Fig. 8. The spore is larger than in Fig. 8 and the chromosome is in the long axis.

Fig. 10. Strain Hankow Hide, $8 \frac{1}{2} \mathrm{hr}$. incubation. The chromosome is bent into a horse-shoe shape.

Figs. 11 and 12. Later stages of Fig. 10 showing expanding rings of chromatin.

Fig. 13. Completely basophilic spores, similar to those seen in one stage of germination.

Fig. 14. Strain C1. Resting spores, hydrolyzed at room temperature, by oblique illumination, showing the spore chromosome and the outer spore membrane.

Fig. 15. Strain Carrickfergus after $3 \frac{1}{2} \mathrm{hr}$. incubation at $37^{\circ}$ and $1 \mathrm{hr}$. at $4^{\circ}$ showing clumping of nuclear material.

Fig. 16. Strain Tinsdale. Coccal variants, showing the single chromosome. Dividing forms show two chromosomes. $3 \mathrm{hr}$. incubation. Photograph by Dr C. F. Robinow.

Fig. 17. C. diphtheriae, 10-day culture on Neill's blood-tellurite medium, showing single chromosome, photographed in light of the $435.8 \mu$ band of the mercury arc. 